Hydraulic Engineering Repository

Ein Service der Bundesanstalt für Wasserbau

Keaton, Jeffrey R.; Mishra, Subhendu K.; Clopper, Paul E.; Lagasse, Peter F. Hydraulic Loading for Bridges Founded on Rock

Verfügbar unter / Available at:

https://hdl.handle.net/20.500.11970/100293

Vorgeschlagene Zitierweise / Suggested citation:

Keaton, Jeffrey R.; Mishra, Subhendu K.; Clopper, Paul E.; Lagasse, Peter F. (2010): Hydraulic Loading for Bridges Founded on Rock. In: Burns, Susan E.; Bhatia, Shobha K.; Avila, Catherine M. C.; Hunt, Beatrice E. (Hg.): Proceedings 5th International Conference on Scour and Erosion (ICSE-5), November 7-10, 2010, San Francisco, USA. Reston, Va.: American Society of Civil Engineers. S. 734-742. 


\title{
Hydraulic Loading for Bridges Founded on Rock
}

\author{
Su K. Mishra ${ }^{1}$ M. ASCE, Ph.D., P.E., Jeffrey R. Keaton ${ }^{2}$ F. ASCE, Ph.D., P.E.,
} Paul E. Clopper ${ }^{3}$ M. ASCE, P.E., and Peter F. Lagasse ${ }^{4}$ F. ASCE, Ph.D., P.E.

${ }^{1}$ Senior Technical Advisor, HDR, 2365 Iron Point Road, Suite 300, Folsom, CA 95630; PH (916) 817-4860; email: su.mishrarahdrinc.com

${ }^{2}$ Senior Principal Engineering Geologist, MACTEC, 5628 East Slauson Avenue, Los Angeles, CA 90040, jrkeatonamactec.com

${ }^{3}$ Senior Hydraulic Engineer, Ayres Associates, 3665 JFK Parkway, Suite 200, Fort Collins, CO 80525, clopperparavresassociates.com

${ }^{4}$ Senior Vice President, Ayres Associates, 3665 JFK Parkway, Suite 200, Fort Collins, CO 80525, lagassep a ayresassociates.com

\section{ABSTRACT}

Instantaneous stream power is defined as the product of shear stress and stream velocity representing the scouring condition. Hydraulic loading conditions are being expressed in terms of stream power which can be accumulated over the life of a bridge structure. The prediction of scour in erodible rock must consider the hydraulic loading imposed over many years over all the flood events over those years. This is true whether or not a threshold condition must be exceeded before the rock in the streambed is exposed to erosive forces. Long-term observations of scour in erodible rock combined with a history of hydraulic loading (expressed as stream power) provide a valuable index of the relative erodibility of the particular rock formation. An index, herein described as the Scour Number $\mathrm{K}_{\mathrm{s}}$, is defined as the amount of scour observed over a period of time divided by the cumulative hydraulic load over the same period. Given a future cumulative hydraulic loading, the Scour Number can be used to estimate the future scour associated with that loading, for the particular rock formation. Probability weighted flood frequency captures the range of flow conditions and is converted to average annual scour.

\section{INTRODUCTION}

The failure of the Interstate Highway 90 (I-90) Bridge over Schoharie Creek in New York during a flood in 1987 resulted in a Federal Highway Administration mandate for all bridges over water to be evaluated for scour susceptibility. Evaluating Scour at Bridges, Hydraulic Engineering Circular No. 18 (HEC-18; Richardson and Davis, 2001), has served the transportation community well for bridges founded on cohesionless, granular soils. HEC-18 procedures do not address cohesive soil or materials that are cemented or indurated (rock or rock-like formations). The I-90 Bridge over Schoharie Creek that failed in 1987 was founded on a glacial till formation that apparently was too hard to drive piles into when the bridge was constructed in 1954. Progressive scour from successive flood events undermined the spread footings but went undetected apparently because of an armoring layer of boulders and cobbles.

For short-term analysis like scour in non-cohesive material a single event such as the 100-year flood is typically selected for design purposes. However, scour in 
rock is a process that must be considered over the long term (e.g., the remaining service life of the bridge). For a long-term approach, the objective is to evaluate the cumulative effects of a range of flow conditions. Therefore, a probability-weighted approach originally developed by Lagasse et al. (1985) to estimate average annual sediment yield using recurrence-interval events was adapted for use in predicting an equivalent average annual depth of scour in erodible rock. The method is straightforward in concept and simple to apply.

\section{STREAM POWER}

Power is defined as a rate of doing work or a rate of expending energy. In open channel flow, instantaneous stream power (the stream power at any particular moment) is defined as:

$$
P=\gamma q S_{f} L=\gamma q(\Delta E)
$$

$$
\text { where } \begin{array}{ll}
\mathrm{P} & =\text { Instantaneous stream power, } \mathrm{kW} / \mathrm{m}^{2}(\mathrm{lb}-\mathrm{ft} / \mathrm{s} \text { per square foot) } \\
v & =\text { Unit weight of water, } 9,800 \mathrm{~N} / \mathrm{m}^{3}\left(62.4 \mathrm{lb} / \mathrm{ft}^{3}\right) \\
\mathrm{q} & =\text { Unit discharge, } \mathrm{m}^{3} / \mathrm{s} \text { per meter width }\left(\mathrm{ft}^{3} / \mathrm{s} \mathrm{per} \mathrm{foot} \mathrm{width)}\right. \\
\mathrm{S}_{\mathrm{f}}=\text { Slope of the energy grade line, } \mathrm{m} / \mathrm{m}(\mathrm{ft} / \mathrm{ft}) \\
\mathrm{L}=\text { Unit distance in direction of } \mathrm{flow}, \mathrm{m}(\mathrm{ft}) \\
\Delta \mathrm{E}=\text { Energy loss per unit distance in direction of flow }
\end{array}
$$

In terms of shear stress and velocity, Equation (1) may be rewritten as

$$
P=\tau V
$$

$$
\text { where } \begin{array}{ll}
\tau & =\text { Representative shear stress, } \mathrm{N} / \mathrm{m}^{2}\left(\mathrm{lb} / \mathrm{ft}^{2}\right) \\
\mathrm{V} & =\text { Representative velocity, } \mathrm{m} / \mathrm{s}(\mathrm{ft} / \mathrm{s})
\end{array}
$$

The shear stress and velocity in Equation (2) must represent the conditions for which the scour is being evaluated. For example, if long-term scour across the entire cross section is of interest, the cross-sectional average velocity and bed shear will be satisfactory for use. However, if the scour at a specific location in the cross section is of interest, for example at a pier, then it is more appropriate to use local values for these variables. The maximum stream-tube velocity in the cross section $V_{\max }$, multiplied by a shape factor $K_{p}$ to account for local acceleration around the pier, will provide a more suitable representation of local conditions at the pier itself. Shape factors $\mathrm{K}_{\mathrm{p}}$ are typically taken as 1.5 for round-nose piers and 1.7 for blunt (or squarenosed) piers, while the local shear stress is given as:

$$
\tau=(n V)^{2}\left(\frac{\gamma}{y_{0}{ }^{1 / 3}}\right)=\left(\frac{n V}{1.486}\right)^{2}\left(\frac{\gamma}{y_{0}{ }^{1 / 3}}\right)
$$

where $\tau=$ Local shear stress at the pier, $\mathrm{N} / \mathrm{m}^{2}\left(\mathrm{lb} / \mathrm{ft}^{2}\right)$

$\mathrm{n}=$ Manning's $\mathrm{n}$ roughness coefficient 


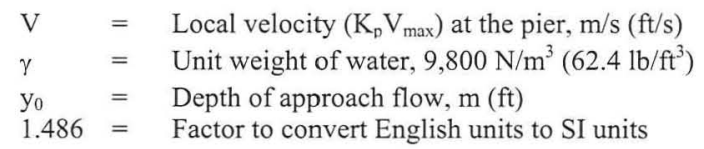

Substituting the expression for shear stress in Equation (3) into Equation (2) reveals that stream power is directly proportional to the cube of velocity. Therefore it is important that the location and magnitude of the representative velocity is selected with care. For example, computing stream power in the immediate vicinity of a square-nosed pier with a shape factor $K_{p}$ of 1.7 will result in a stream power of $(1.7)^{3}$ $=4.9$ times greater than the approach stream tube velocity just upstream of the pier.

\section{INTEGRATED STREAM POWER}

Integrated (or total) stream power, denoted $\Omega$, is the area under the curve of stream power versus time for any particular flow duration, and is expressed in units of work (or energy loss) per unit area $\left(\mathrm{kW}-\mathrm{hr} / \mathrm{m}^{2}, \mathrm{lb}-\mathrm{ft}_{\mathrm{ft}}{ }^{2}\right)$. Using a time series of average daily flows typically obtained from USGS gaging station records, a time series of average daily stream power can be constructed as shown in Figure 1 which illustrates typical data from a single water year.
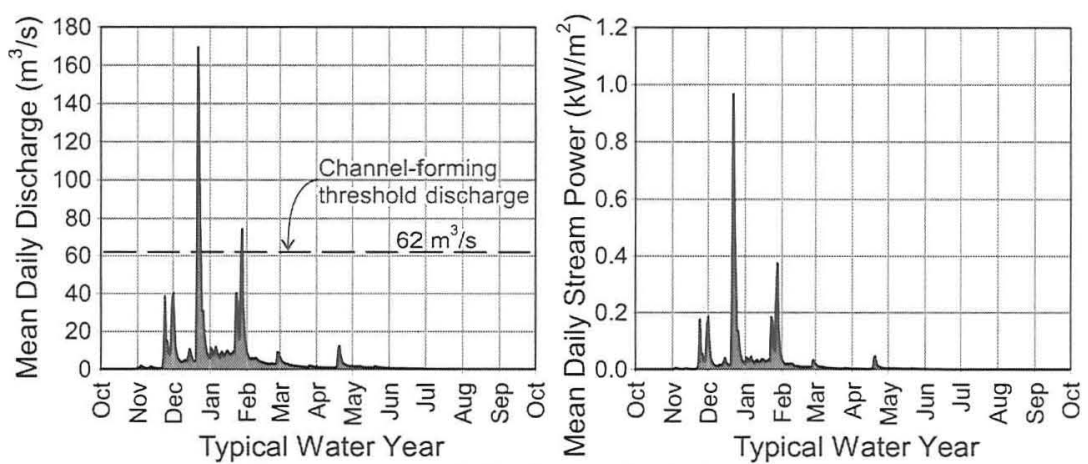

Figure 1. Transforming a mean daily flow series into mean daily stream power.

Integrated stream power shown in Figure 1 expressed in U.S. customary units is $\mathrm{lb}-\mathrm{ft} / \mathrm{s} / \mathrm{ft}^{2}$-day, since the time-base of the mean daily flow series is one day. Multiplying this value by 86,400 seconds per day gives $\mathrm{lb}-\mathrm{ft} / \mathrm{ft}^{2}$, but the values themselves become cumbersome to work with; therefore, daily stream power is used.

\section{THRESHOLD CONDITIONS}

The physical processes involved in the scour of erodible rock may require that a threshold hydraulic condition be exceeded before scour can occur. Such thresholds could be, for example, a critical velocity, critical shear stress, critical stream power, or a geomorphic indicator such as a bank-full or "channel-forming" discharge. This can be an important process in many streams where relatively thin layers of gravel or cobbles overlie the rock in the streambed. These coarse bed materials must be 
mobilized by a threshold hydraulic load before the underlying rock is exposed. Once the threshold is exceeded, however, the rock is exposed to the hydraulic forces of the flow, as well as to abrasion by the coarse bed materials that become mobile.

To illustrate this concept, consider the case where "effective" stream power is associated with a threshold value corresponding to a 2-year flood event, which is considered a channel-forming flow for a particular site. Flows less than the 2-year event therefore contribute no work towards eroding the rock of the streambed; however, once the 2-year value is reached or exceeded, the rock is exposed to the total stream power. The relationship between effective stream power and the threshold condition (in this case, discharge) is illustrated by Figure 2.

Using data from the time series shown in Figure 1, the graph of effective stream power vs. time is illustrated by Figure 3. Note in this figure that only two flood events in this particular water year exceeded the threshold condition, and active erosion of the rock (in this example) occurred over a total of only four days during the entire year. Both the daily series and the cumulative total stream power for the year are shown in this figure.

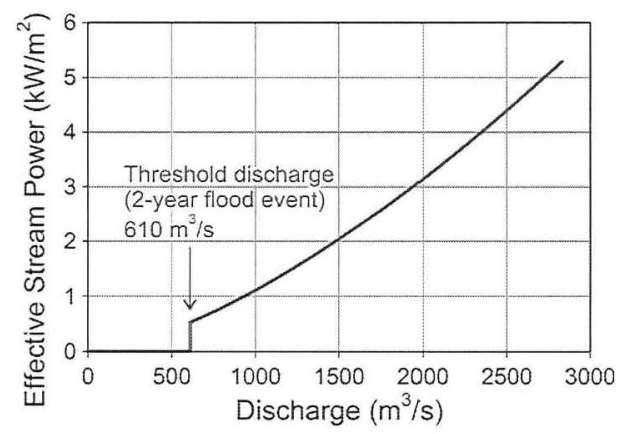

Figure 2. Effective stream power vs. discharge with a threshold condition.

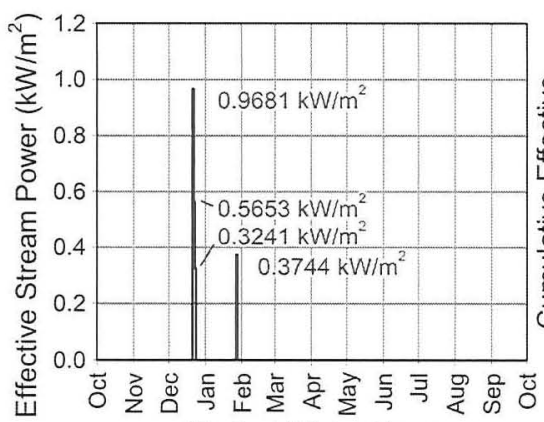

Typical Water Year

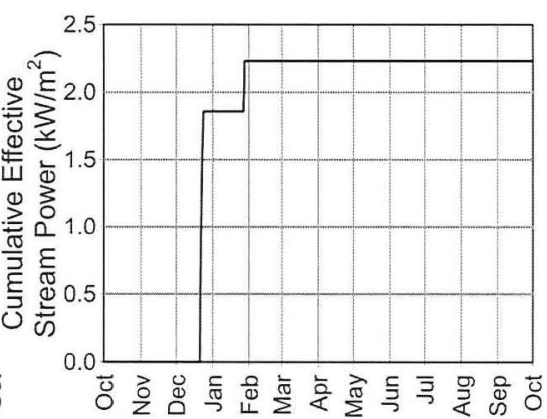

Typical Water Year

Figure 3. Effective stream power vs. time with a threshold condition. 
Selection of a value for a threshold condition can be based or the caliber of bed load material protecting the rock channel or it can be based of geomorphic conditions, such as bankfull discharge. Geotechnical laboratory test results may be helpful in guiding selection of threshold hydraulic parameters for defining "effective" stream power. Additional research is needed on the stream-power threshold topic.

\section{LONG-TERM CUMULATIVE STREAM POWER}

The prediction of scour in erodible rock must consider the hydraulic loading imposed over many years by many flood events. This is true whether or not a threshold condition must be exceeded before the rock in the streambed is exposed to erosive forces. Consider the 71-year period of record of mean daily flows from 1938 to 2009 for the Sacramento River from USGS gaging station 11370500 at Keswick, California shown in Figure 4. For this reach, a 2-year event of $859 \mathrm{~m}^{3} / \mathrm{s}$ is assumed to be the channel-forming discharge and will be used as a threshold condition to develop the long-term hydraulic loading (in terms of stream power) at this location.

State Route 273 crosses the Sacramento River near the Keswick gaging station. Comparison of survey data from January 1971 and November 2004 revealed that approximately $1.524 \mathrm{~m}$ of scour in the streambed rock (siltstone) in the vicinity of Piers 4, 5, and 6 had occurred over this period of time (approximately 33.8 years). From the graph of cumulative daily stream power for the Sacramento River at the SR 273 Bridge (Figure 5), the cumulative amount of effective daily stream power (i.e., contributed by events exceeding the 2 -year discharge) in the 33.8 years between these two observations was approximately $336.5 \mathrm{~kW} / \mathrm{m}^{2}$.

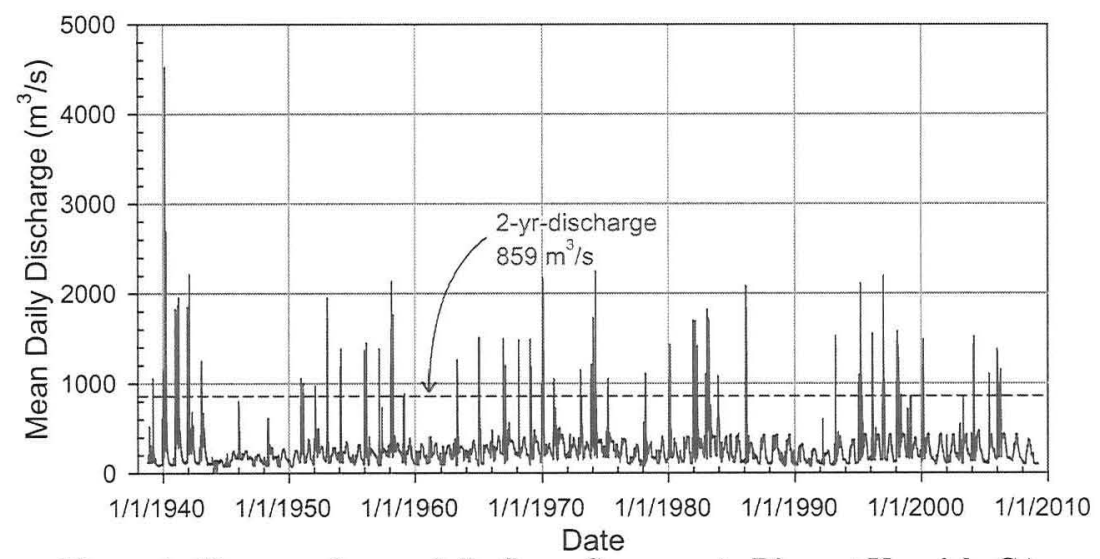

Figure 4. 71 years of mean daily flows, Sacramento River at Keswick, CA. 


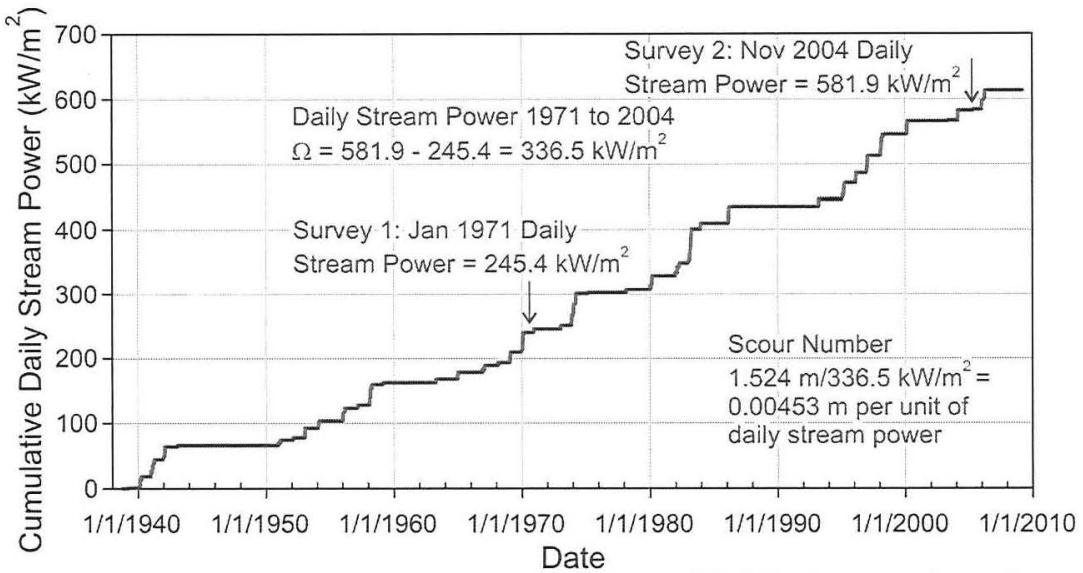

Figure 5. Long-term cumulative stream power, SR 273 pier scour in rock.

Long-term observations of scour in erodible rock combined with a history of hydraulic loading (expressed as stream power) provide a valuable index of the relative erodibility of the particular rock formation. In the case of the SR 273 Bridge over the Sacramento River, $1.524 \mathrm{~m}$ of pier scour over a 33.8-year period can be related to a cumulative hydraulic load over that same period of time. An index, herein described as the Scour Number $\mathrm{K}_{\mathrm{s}}$, is defined as the amount of scour observed over a period of time divided by the cumulative hydraulic load over the same period:

$$
\mathrm{K}_{\mathrm{s}}=\mathrm{y}_{\mathrm{s}} / \Omega
$$

where $\mathrm{K}_{\mathrm{s}}=$ Scour Number, $\mathrm{m}(\mathrm{ft})$ per unit of effective stream power

$\mathrm{y}_{\mathrm{s}} \quad=$ Observed scour, $\mathrm{m}(\mathrm{ft})$ over a period of time

$\Omega \quad=\quad$ Cumulative effective daily stream power over the same period of time as the observed scour

Given a future cumulative daily hydraulic loading $\Omega_{\text {fut }}$, the Scour Number can be used to estimate the future scour associated with that loading for the particular rock formation that was scoured to give the scour number. Estimates of future scour may then be made for a variety of purposes:

- Predicting scour over the remaining life of a structure

- Predicting scour at other existing structures with foundations in the same (or similar) rock formation

- Predicting scour at proposed structures on similar rock formations.

The difficulty with the above approach is estimating the cumulative effective hydraulic load in the future. Many rock scour issues are concerned with plucking or quarrying processes in durable, jointed rock for which a threshold condition applies; therefore, only the effects of larger, relatively infrequent events over the life of the structure need be considered. Scour in erodible rock is gradual and progressive, which lends itself to a process model known as the probability-weighting approach. 


\section{PROBABILITY-WEIGHTED APPROACH}

Using either observed scour depths vs. cumulative stream power over time, or an erosion rate relationship based on rock properties, an erosion rate function for recurrence-interval flood events for a particular site is defined as

$$
\left(y_{s}\right)_{i}=f(\Omega, t)
$$

where $\left(y_{s}\right)_{i}=$ Scour depth associated with a flood of recurrence interval $i$, where $i=2,5,10,25,50,100$, or 500 years

$\Omega \quad=$ Total stream power associated with the recurrence interval flood $\mathrm{t}=$ Duration of the flood, days

The probability weighted approach accounts for the probability of occurrence of various flood events during any one year. For example, if $\left(y_{s}\right)_{i}$ is the scour associated with a given flood of recurrence interval $i$, and $\mathrm{P}_{\mathrm{i}}$ is the annual probability that the given flood will occur, then the product $\left(\mathrm{y}_{\mathrm{s}}\right)_{\mathrm{i}} \times \mathrm{P}_{\mathrm{i}}$ represents the contribution of that given flood to the long-term mean annual scour depth. To account for the contribution of all possible floods requires the integration

$$
\bar{y}_{s}=\int_{0}^{1}\left(y_{s}\right)_{i} d P_{i}
$$

This integration is easily accomplished using the flood frequency curve. The frequency curve for scour associated with each recurrence-interval flood is developed by computing the scour using Equation (5). Figure 6 illustrates a typical scourfrequency curve. The area under the curve represents the mean annual scour depth, and can be computed either graphically or numerically. A simple approximation is a stepwise integration using Simpson's Rule as follows:

$$
\begin{aligned}
& \bar{y}_{s}=0.002\left(y_{s}\right)_{500}+0.008\left(\frac{\left(y_{s}\right)_{500}+\left(y_{s}\right)_{100}}{2}\right)+0.01\left(\frac{\left(y_{s}\right)_{100}+\left(y_{s}\right)_{50}}{2}\right)+ \\
& +0.02\left(\frac{\left(y_{s}\right)_{50}+\left(y_{s}\right)_{25}}{2}\right)+0.06\left(\frac{\left(y_{s}\right)_{25}+\left(y_{s}\right)_{10}}{2}\right)+0.1\left(\frac{\left(y_{s}\right)_{10}+\left(y_{s}\right)_{5}}{2}\right)+ \\
& +0.3\left(\frac{\left(y_{s}\right)_{5}+\left(y_{s}\right)_{2}}{2}\right)+0.5\left(\frac{\left(y_{s}\right)_{2}+0}{2}\right)
\end{aligned}
$$

Expanding Equation (7) and combining like terms, the estimated average annual scour can be simplified to:

$$
\begin{aligned}
& \bar{y}_{s}=0.006\left(y_{s}\right)_{500}+0.009\left(y_{s}\right)_{100}+0.015\left(y_{s}\right)_{50}+0.04\left(y_{s}\right)_{25}+ \\
& +0.08\left(y_{s}\right)_{10}+0.2\left(y_{s}\right)_{5}+0.4\left(y_{s}\right)_{2}
\end{aligned}
$$




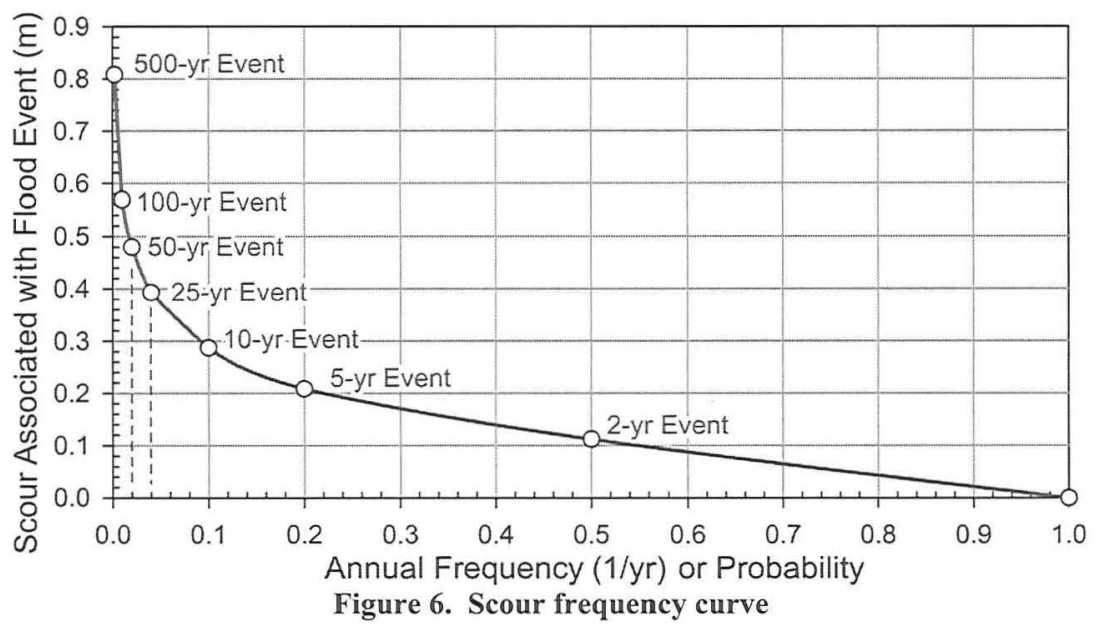

The coefficients in Equation (8) clearly show that the scour contributions from larger, rare flood events are weighted less heavily than the scour from smaller, more frequent events. Thus, over the long term, the total scour at a bridge $y_{\max }$ during its remaining service life $\Delta T$ is estimated to be $y_{\max }=\left(\bar{y}_{s}\right)(\Delta T)$. If one assumes that a threshold condition, for example the 2-year flood, must be exceeded before the hydraulic load (represented by stream power) can begin to erode the rock in the stream bed, the last term of Equations (7) and (8) may be neglected.

\section{CONCLUSION}

The method described in this paper was applied at bridge sites in New York (Schoharie Creek), California (Sacramento River), Florida (Chipola River), and Oregon (Mill Creek) as part of the research work for NCHRP Project No. 24-29. In each of the cases, the method proved to be a suitable procedure to predict long-term scour at bridges founded on rock-like material. The Scour Number $\mathrm{K}_{\mathrm{s}}$ was used to predict the scour over a time period. In subsequent work on this project, samples of rock collected at the bridge sites were subjected to geotechnical testing. An equivalent geotechnical scour number, which is the representative erosion rate based on the response of rock fragments to energy dissipation, was developed which appears to be useful in predicting scour in degradable rock, even in the absence of historical hydraulic loading data. The geotechnical scour number is described by Keaton and Mishra (2010); it is appropriate for rock material that scours by grainscale wear in response to hydraulic loading or abrasion. It is not appropriate for jointed durable rock that scours by quarrying and plucking of blocks defined of joint, fracture, or bedding planes, which is a threshold-controlled process. The geotechnical scour number has been calibrated at only one location: the SR 273 Bridge across the Sacramento River at Redding, California. It is a promising approach that deserves additional research. 


\section{ACKNOWLEDGMENTS}

The research described in this paper is part of a National Cooperative Highway Research Program project to develop guidelines for evaluating scour at bridge foundations or rock (NCHRP Project 24-29). The first author of this paper is the co-principal investigator; he was a Senior Hydraulic Engineer with Ayres Associates during nearly all of the research.

\section{REFERENCES}

Keaton, J.R., and Mishra, S.K. (2010). Modified Slake Durability Test for Erodible Rock Material, Proceedings $5^{\text {th }}$ International Conference on Scour and Erosion (this conference).

Lagasse, P.F., Schall, J.D., and Peterson, M. (1985). Erosion Risk Analysis for a Southwestern Arroyo, Journal of Urban Planning and Development, Vol. 111. No. 1.

Richardson, E.V., and Davis, S.R. (2001). Evaluating Scour at Bridges. Hydrologic Engineering Circular 18, Federal Highway Administration, 4th Edition, Publication No. NHI 01-001, 378 p. 